\title{
Forgotten Solidarities in the Atelier Populaire Posters
}

Antigoni Memou University of East London (U.K.)

\begin{abstract}
:
The paper examines some of the 'forgotten' posters of the Atelier Populaire, which were collectively produced by artists, workers, students and activists among others in the occupied Beaux-Arts school during the events of May '68. The paper argues that alternative visual narratives are to be discovered in these posters, which break away from the representations of the events as youth revolt and the geographical reduction of the events to Paris and the Cartier Latin. Looking at them anew allows us to rediscover the unique solidarity among students, workers, farmers, the migrant workers and the unemployed, as well as to decipher the anti-capitalist character of the movement and its global dimensions.
\end{abstract}

Keywords: Atelier Populaire, posters, May '68, posters, solidarity, anti-capitalist movement

A double-spread photograph featuring six female models in 1960s haute couture outfits, posing in front of barricades erected in the parking lot of the Cartier Foundation building in Paris. This double-spread photograph accompanied Paris Match's review of their 1986 exhibition entitled Les Annees 60: 1960-1969: La Decade Triomphante. ${ }^{11}$ The models are posing in front of a 
highly stylized background of staged barricades, while dry ice was produced by a smoke machine. Against this artificial smoke, two young men stood on top of the barricades in 'rebellious' poses, one holding a red flag, the other with a raised clenched fist. A placard declaring: 'Il est Interdit d' Interdire' ('It is forbidden to forbid') replicates the celebrated slogan of the May ' 68 uprisings. The smoke, the barricades, the young men and the placard represent the students and workers revolt in Paris during the months of May and June in 1968 and are employed in the photograph as the backdrop to some of the most memorable achievements of the 60's: high fashion, luxury consumer goods and glamorous celebrities. The luxury cars of the era, which were parked on the lawn of the Foundation, highlighted the exhibition's focus on the 1960s as a decade of innovative fashion and luxury goods, themes that would appeal to Cartier's clientele.

This highly constructed image acts metonymically, to reflect both the focus of the Foundation's show, and the cultural and political narratives that dominated France during the 70's and 80's: that the spirit of May '68 was finished, its ideas outmoded, its iconography merely a stylish background for the showcasing of the decade's consumer goods and popular culture -regarded officially as the 1960s' most important developments. Photographs, graffiti, political cartoons and posters produced during the events have also been extensively used in commemorative exhibitions and media representations, contributing to the construction of the collective memory of the period. Despite the rich visual legacy of May '68 though, specific photographs and posters have been are used repeatedly to become the 'canonical' images of '68. This raises important questions about what is left out of sight and which parts of this visual legacy have been 'forgotten.' It also highlights how images either constructed -as in the case of the Cartier exhibition- or documentary have served to highlight the cultural implications of the movement, 
its emphasis on freedom of expression and sexual liberation, often obscuring the radical potential and political dimension of the events.

The denunciation of 1968 's emancipatory potential and its revolutionary aspirations has been part of larger dominant narratives constructed in France since the 1970s. Kristin Ross, in her celebrated account of May '68, illuminates how sociologists, philosophers and politicians among others have attempted to reduce May ' 68 to a harmless youth revolt, which heralded the triumph of individualism and the emergence of neoliberalism (Ross. 2002). The emergent so-called 'new philosophers' put forward some of the best known arguments: Luc Ferry and Alain Renaut asserted that the thought of ' 68 was a premonition of the rise of late capitalism's contemporary individualism (Ferry and Renaut 1985), and Gilles Lipovetsky claimed that 'the 68 spirit' contributed decisively in precipitating narcissistic individualism's actualization as the dominant form of contemporary subjectivity (Lipovetsky: 1983). Other commentators went even further, arguing that effectively, nothing much happened in May '68. Raymond Aron spoke of 'the event that turned out to have been a non-event' and Pierre Nora categorically asserted that 'not only was there no revolution, but nothing tangible or palpable occurred at all.' (Aron1969: ix; Nora quoted in Ross 2002: 186). In the public arena, Presidential candidate Nicolas Sarkozy attacked the 'cynical' and 'immoral' Left that systematically supports thugs and troublemakers against the police and called for the 'liquidation' of May '68's legacy during his pre-electoral campaigning in 2007.

All these systematic efforts to erase May '68's radical potential from official memory give rise to questions about the importance of maintaining the visibility of May 68's radical and collective action as part of a critical and radical tradition that can inform the formulation of new demands, new forms of resistance and practices of oppositions in current and future struggles. This 
requires revisiting less reproduced visual documents and unpublished archival material in order to rediscover forgotten aspects of this extraordinary political movement. This paper reconsiders the collectively produced posters of the Atelier Populaire-the occupied Beaux-Arts school-and sheds light to important themes that have been overlooked. It argues that alternative visual narratives are to be discovered in this 'forgotten' material, which breaks away from the representations of the events as a youth revolt and the geographical reduction of the events to Paris and the Cartier Latin. The Atelier Populaire posters demonstrate the unique solidarity between students, workers, farmers, professionals, migrant workers and anti-colonial militants, the experiments in direct democracy and the networks of communication with other struggles around the globe.

\section{The Collective Image of the Movement}

As is well known, the 1968 movement in Paris started at the Nanterre campus in March 1968 and expanded to the Sorbonne and other branches of the university at the beginning of May. The student mobilisations, including occupations of the university buildings, organised demonstrations and public meetings, were met with extreme violence from DeGaulle's administration. The students' mobilisations culminated on the $10^{\text {th }}$ of May, when the students, in response to police brutality, built barricades in the narrow streets of the Latin Quartier, reviving revolutionary methods earlier French popular uprisings, in 1830, 1848 and in Paris Commune. The brutal violence performed by the police incited the general public's support towards the movement. The workers went on strike on the $13^{\text {th }}$ of May and this was followed by a strike in all sectors -including public transportation, gas stations and mass media, which paralysed the 
country until the end of May. What initially manifested as a crisis within academic institutions, expanded to form a broad-based critique of authoritarian and hierarchical societal structures, which engaged diverse social groups including students, workers, professionals and the unemployed.

The emphatically collective nature of the events of May '68 was evident in the innovative plurality of the direct actions mounted by its activists, which included sit-ins, teach-ins, consciousness-raising groups, marches to factories and the occupation of public and private spaces. The absence of central leadership and hierarchy was encapsulated in the organisation of comités d'action (action committees), -some of which pre-existed- which augmented to reach 460 only in the region of Paris by the end of May (Ross 2002: 76). Comités d'action consisted of ten to fifteen people, activists and people with no prior experience of political organisation and operated on a local basis, in neighborhoods, high schools, universities and factories. These innovative forms of organisation refused to assimilate the function of the existing political parties, unions or groupuscules and aimed to occupy the space between political leadership and the collective body that came out onto the streets for the demonstrations. This was politics from 'bottom up' as one tract put it: 'The fundamental goal of the comités $d$ ' action is to define a common political line from the bottom up (à partir de la base.) (Bulletin 1968). These new political practices resisted bourgeois notions of hierarchy, leadership and professional specialization, which underpinned systems of political representation. 
The refusal of assigned roles and the social division of labour was also put in practice by artists in the occupied Beaux-Arts. The Comité des grèves des Beaux Arts occupied the painting and lithography ateliers and established Atelier Populaire de Beaux Arts, or as is better known, Atelier Populaire on the $14^{\text {th }}$ of May. The first poster produced on the day celebrated the solidarity between the students and workers with the slogan 'Usines, Universités, Union' ('Factories, Universities, Union.') The slower processes of lithography and serigraphy were soon replaced by the speedier silk-screening process, which facilitated the printing of posters resulting in up to 2000 copies being printed at one time (Vermès 2011: 10). The Atelier Populaire was run by general assemblies, which consisted of artists, workers, professionals, students and members of the general public. Everyone could contribute slogans and ideas to the General Assembly (GA) and debate the posters' content and political messages. Everyone could also offer their labour, if they followed the principles written on the walls of the studio: 'Camarades creatures: se mettre au service des travailleurs en lute, c'est travailler sur des slogans acceptés par l'AG. Trabailler sur sa petite idée personnelle, même juste, c'est rester dans la cadr étroit de la conception bourgeoise.' ( 'Comrades creators: to serve the workers in struggle is to work on slogans accepted by the GA. To work on one's own personal idea, even if fair, is to remain in the narrow frame of the bourgeois conception') (Wlassikoff et.al. 2008: 12). The conceptualization and production was, therefore, a non-hierarchical, collective process, which defied notions of individual creativity, authorship and social division of labour. The hand-written sign stuck on the door of the Atelier encapsulated this spirit: 'Atelier Populaire Oui, Atelier Bourgeois Non', reaffirming the rejection of bourgeois social norms and its popular/non-elite audience. 
The immediacy of the poster as an artistic technique allowed the proclaimed revolutionary Atelier Populaire to speedily respond to the needs of the movement. The movement foregrounded the immediacy to abolish the boundaries between art and life and to bring art to the service of the struggle. Gérard Fromanger, one of the artists involved in the Atelier Populaire highlighted this urgency: 'May 68 was that. Artists are no longer in their studios, they no longer work, they cannot work anymore because the real is more powerful than their interventions. Naturally, they become militants, me among them. We create the Atelier Populaire des BeauxArts and we are making posters. We are there night and day making posters. The whole country is on strike and we've never worked harder in our lives. We're finally necessary.' (Fromanger, 1998) Atelier Populaire attempted to put in practice the utopian elements of the Situationist International's avant-garde ambition to achieve a revolution through the collapse of art into life. The founding text of the Atelier Populaire highlighted the role that art had to play in the struggle against capitalism and exploitation. Written on the $15^{\text {th }}$ of May, it claimed among others: 'we find fault with the role that society expects of intellectuals: to be the guard dogs of the system of economic production, to be a technocratic cadre, to act so that everyone is happy in his place, especially when his place is one of exploitation.' (Kugelberg and Vermès 2011: 205). There was clearly an emphasis on negating the bourgeois role of the artist in a capitalist society, as well as on establishing links with the workers' struggle. The direct and radical slogans were clearly anticapitalist: they questioned the bourgeois society and rigorously denounced the privileged status by which 'bourgeois culture' isolated artists from other workers.

The Atelier Populaire distributed a text instructing the silkscreen printing process, which could be put in practice in poster workshops in occupied factories and across the country. The posters 
were, therefore, along with leaflets, tracts, fliers and underground newspapers, produced anonymously and collectively by the action committees and distributed across the country, in the biggest printing boom since the Resistance (Ball 2010: 77). The leaflets bore testimony to the police brutality, called for action and less often, printed cartoons and poems or reprinted articles from mainstream newspapers (Ball 2010: 81, 85, 86). Similarly, the newspapers that came out of the students' political groups flourished in the months of May and June. Action, which represented the UNEF, the SNEsup and the March 22 movement was notable for the absurdity, eccentricity and humour of its slogans and cartoons, frequently by Siné, the renowned anticolonialist and anti-capitalist French political cartoonist. The newspaper often had a detachable front page, which could be used as a street poster.

The posters were plastered on the street walls and around the occupied university, bringing the poetry into the street, as one slogan declared ('La Poésie est dans la Rue'/'Poetry is in the Street.') The public space was reclaimed by the protesters, who also graffitted many of the movement's slogans on the Parisian walls, interrupting the urban fabric of everyday life. Slogans such as 'L' Art est Mort-Ne Consommez Pas Son Cadavre?', ('Art is Dead, Do not Consume its Dead Body?'), 'Sous Les Pavés, la Plage' ('Under the Paving Stones, the Beach'), 'La barricade Ferme la Rue mais Ouvre la Voie' ('The Barricade Closes the Street but Opens the Way') were among the ones graffitted by the anonymous collective body, defying any defied any notion of authorship and property. Now accessible through photographs, such as the ones by Jo Schnapp 1998 \& Michel 1998, they 'performed an immanent critique that allowed myriad anonymous producers to appropriate and insinuate themselves into the architectural fabric of daily social life by means of graffittied words.' (Stracey2014: 78) ${ }^{2}$.Both posters and graffiti attempted to re- 
territorialise the public space from below and transform the urban environment as part of their revolutionary project.

The posters also formed one source of counter-information to the mainstream new platforms. For this purpose, at the beginning of June, Atelier Populaire also printed five poster-size 'Wall Newspapers', which brought together news from various action committees and from the strikes and protests, challenging the governmental sources of information (Kugelberg and Vermès 2011: 238-239). This seemed to be a realization on the behalf of the movement that the posters were weapons in their struggle, which could shape the events. The posters speedily responded to the governmental and police repressive actions, but after the nationwide strike of producers, and technicians in state radio and television, the ORTF, on the $25^{\text {th }}$ of May, the posters along with the tracts, leaflets and students' underground publications played a crucial role in the circulation of information within the wider society. It became clear that the movement invented its novel circuits of distribution of 'counter-information', which challenged the official coverage of the events by the heavily censored Radio Television Française (RTF).

The criticism of the censorship imposed by the government also became the theme of many posters. In the monumental exhibition catalogue by the Beaux-Arts de Paris supported by the Ministry of Culture 'Images en Lutte' the posters' themes are categorised as follows: the attack towards DeGaulle and its repressive and authoritatian government; the criticism of the riot police, C.S.R. (Compagnies Républicaines de Sécurité) which personified the repression and violence of the capitalist state; the defence of the workers as victims of capitalist exploitation and 
the support of their strikes; the support of various struggles including the transport strikers and the strikes in the factories of Citröen, Peugeot, Renault; the critique of parliamentarism and the Grenelle agreements; the criticism of the press; the critique of capitalism and imperialism; the solidarity between students and workers; a reaction to the expulsion of foreigners. (Beaux-Arts de Paris 2018: 70-72) While these general categorisations capture the major themes tackled in the posters, they do not emphasize that the alliance between the different societal groups was one of the most celebrated theme of the posters. Shedding light to the solidarity not only among the students and the workers, but also the farmers, the migrant workers and the unemployed allows us to decipher the anti-capitalist character of the movement and its international impact.

\section{Forgotten Alliances in Paris and Beyond}

Ross in her book on May '68 argues that the dominant narrative configurations of the events of May were based the geographical and temporal reductions (Ross 2002: 8-10). Ross demonstrates how the events have been restricting to the month of May, taking out of the picture the emergence of a pre-68 radical political culture manifest in small, but significant opposition to the Algerian war, the workers' unrest in the mid-1960s, the rise of Anti-Stalinism since the 1950s and the dominance of Marxism flourishing in journals, in parts of the workers' movements and in the small groups of Maoist, Trotskyist and anarchist militants (Ross 2002: 8-9). At a geographical level, the official story reduces the events to Paris and most notably, to the Latin Quarter, where the iconic barricades and the clashes between the students and the police took place. This temporal and geographical reduction has resulted in rendering the student, 
predominantly male, as the main actor of the events excluding the workers, professionals, farmers and colonial militants from the dominant history.

The most reproduced photographic documents of the time reaffirm that this was an uprising that unfolded in the streets of Paris and were led by students. Most of these documents that are commonly seen in books, media and commemorative exhibitions are photographs taken by photojournalists, who took to the streets of Paris as soon as the uprising began. The photoreportages by Bruno Barbey, Gilles Caron, Claude Dityvon, Ellie Kagan, Henri Cartier Bresson and Marc Riboud, who were among the photojournalists who covered the events, were actualised in the streets of the capital. ${ }^{3}$ Within their photographs of demonstrations, barricades, university occupations and clashes between the protesters and the police, the young male protester of student appearance emerges as the dominant figure. Claude Dityvon's photograph of the young protester with the long hair who throws the stone in a Cartier Latin street has attained an iconic status, dwelling into the collective memory as representative of the movement and obscuring visual representations, which are at variance with the stereotypical figure of the young (often violent) protester.

This stereotypical configuration of the actors in the events of '68 is consistent with analyses of May as a 'youth revolt', which emerged from new values and forms of action created by 'postindustrial' society. Alain Touraine argued that May '68 was the beginning of new type of conflict, 'in which new social classes misplaced the working class from the centre of the revolutionary process (Touraine 1971: 27-28). May '68 was then, conceived as a 'new social 
movement', whose emphasis on lifestyle, identity and culture differentiates it significantly from the old labour movement (Melucci 1981: 179). The emphasis on the cultural, socio-political and not strictly economic character of the struggle led the above sociologists to claim that class struggle was of diminishing importance and May '68 was a movement against technocracy and not against capitalism. In those readings, the extraordinary coalition between students, the various Leftist groupuscules, the professionals, the workers and their trade unionists, the farmers and the unemployed was downplayed. Ross takes a critical standpoint towards such analyses: May " 68 'was above all not a revolt on the part of the sociological category of "youth." It was the revolt of an historically situated cross-section of workers and students alike, for some of whom the War in Algeria provided the background noise of their childhood, whole adolescence or adulthood coincided with the massacre of hundreds of Algerian workers at the hands of Papon's police on October 17, 1961 with Charonne and the near-daily attacks of the OAS. These people were not necessarily of the same age, nor were they all embarked on the same political trajectory, but they all saw, in the context of the final years of the Algerian War, to what use the Gaullist regime put their police.' (Ross 2002: 26).

This intergenerational alliance is expressed in a number of posters, which bring together the figures of the student, the worker and the farmer. While farmers appear less often in the posters, the alliance between the students and the workers is absolutely at the centre of the production in the occupied Beaux-Arts. The first lithographic poster produced on the $14^{\text {th }}$ of May (one day after the workers went on strike) read 'Usines, Universités, Union' (Factories, Universities, Union), with a uniform ' $U$ ' at the left side of the poster. [Figure 1] While all three words are in different font and scale, the ' $U$ ' is in the same bold lettering as the word union leaving no doubt 
about the main message of the slogan. The lithographic poster was printed in a run of thirty, but as of the $22^{\text {nd }}$ of May when the Citröen workers went on strike, more posters with the slogan 'Students, Workers. Solidarity’ were produced. This exceptional alliance, united action and active solidarity had no equivalent in any other European country and it was actualised in the large, open, anti-hierarchical assemblies, where everyone had the opportunity to talk. This led to a displacement according to which the various groups-of students, workers and farmers- broke away with places assigned to them by the state and the police. The workers attended the assemblies in the university; the students walked to the factories to meet workers; farmers, workers and students met in local action committees and neighborhood assemblies. These were 'political experiments in declassification, in disrupting the national "givennes" of places.' (Ross 2002: 25). In this way, the different social groups were not focused on their group's interests, but they opened up to the interests, demands and struggles of the 'Other.' The government attempted and partially, succeeded in separating these groups in order to deal with each group individually and more effectively. The government's strategy was favoured by the trade unions' efforts to prevent the dialogue between the workers and the students, to keep the workers off the streets and within the occupied factories, in order to control their generalized strike.

This geographical separation also explicates why there are less photographic documents of the occupied factories, where presumably less photojournalists had access. Nevertheless the photographs taken in the major assemblies within the factories were used by the Atelier Populaire in order to create photo-based posters, by utilizing the opaque projector or the photosilkscreen. Both allowed for photographs to be projected on the paper and led to a creation of the number of posters, which celebrated the workers' strike. Two indicative examples came from the 
occupied Renault Billancourt factory. The first reads 'Tenez Bon Camarades' ('Hold Good Comrades') and 'Notre Arme C' est La greve' ('Our Weapon in the Strike') was based on a photograph depicting the demonstration organized by the students on the $16^{\text {th }}$ of May after the workers in Renault Billancourt went on unlimited strike and occupied the factory. [Figure 2] The second is based on a photograph showing the General Assemblie at the factory on the $28^{\text {th }}$ of May, which rejected the Grenelle agreements with the writing stating 'Nous Irons Jusqu'aubout' ('We Go to the End'). [Figure 3] Both photographs reveal the numerical majority of the striking workers, but also point to the fact that their strikes were confined within the premises of the factory. Nevertheless, pronouns nous/notre (we/our) clearly reveals that there is not separation between the workers' and students' struggles.

What is often overlooked is the emphasis given to the unemployed and migrant workers. Less reproduced posters celebrate the solidarity between the unemployed and employed workers. 'Travailleurs Actifs et Chomeurs Tous Unis' ('Active and Unemployed Workers United') is read in a poster of the $2^{\text {nd }}$ of June, which addresses the presence of the unemployed, a group whose role in the events have been downplayed both in the course of the events and in subsequent representations. [Figure 4] There is also a good number of posters raising attention to the solidarity among French and migrant workers. A smaller number of them utilize a number of different languages acknowledging the linguistic diversity of the workers. The poster 'Travailleurs, Francais, Immigres, Tous Unis' (Workers-French, Immigrants-All United) is followed by the slogan 'A Travail Egal, Salarie Egal' ('For Equal Work, Equal Pay'), which is translated into six different languages. [Figure 5] Quite interestingly, posters bringing attention to migrant labour were produced later in June and July, which only proves Ross's point that 'far 
left groups in May and June acted as a catalyst for distinctly new forms of expression, representation, and mobilization of migrant workers.' (Ross 2002: 95).

\section{'Même Combat' across the Globe}

The chain of cross-border political mobilizations, which emerged worldwide in 1968, never constituted an organised movement. Nonetheless, the informal connections and intellectual exchanges, as well as personal contacts among activists and collaborations, render 1968 a global phenomenon. The pre-existing networks of struggles in the global movements of black people for freedom and rights, the international support of the antinuclear campaign, the transnational network of feminists and the growing anti-war movement following Che Guevara's recent calls to fight against capitalism and war, throughout the 1960s had already set the ground for expansion of international networks between the movements (Fink, Gassert and Junker 1998: 18). The year started with the Tet offensive of the Vietnamese resistance and the Soviet invasion of the Czechoslovak Socialist Republic in the spring, which was followed the subsequent workers' strikes and students' occupations in France, in May, and student demonstrations in Poland, Yugoslavia, Mexico, Germany and Italy in the autumn. The broadcast of the students' uprising and the general strike of nearly ten million workers in France was pivotal in igniting demonstrations of solidarity in Mexico City, Berlin, Tokyo, Buenos Aires, Berkeley and Belgrade (Katsiaficas 1987). The echoes of Che Guevara's recent slogan 'Create two, three, many Vietnams' could be heard both in the growing anti-war movement and in all student movements that arose in the year. It is in particular, the critique of American imperialism and the war in Vietnam, which the French movement shared with the uprisings in Germany, Italy, Japan 
and the United States. As Ross puts it, '[..] Vietnam made possible a merging of the themes of anti-imperialism and anticapitalism; the theoretical justification was loosely provided by Maoism. All revolutionaries are involved in the same struggle (même combat): French workers, the North Vietnamese and even French students have the same enemy, namely imperialist capitalism.' (Ross 2002: 80).

The movement criticized heavily de Gaulle's nationalism, which was at odds with the movement's international solidarity and hostility to anti-semitism. The poster of Cohn-Bendit under the slogan 'Nous Sommes tous des Juifs Allemands!' ('We are all German Jews') exemplified these ideas. [Figure 6] The poster was printed one day after the Counsel of Ministers prohibited Cohn-Bendit's re-entry to France on the $21^{\text {st }}$ of May, while Cohn-Bendit was on a lecture tour in Berlin. The movement was at its peak and the expulsion was the government's conscious effort to devitalise the movement, which was unsuccessful. The Atelier Populaire reacted immediately creating a poster based on a photograph of Cohn-Bendit taken by Jacques Haillot, which showed him in front of a policeman as he emerged from a meeting with the administration at the Sorbonne on the $6^{\text {th }}$ of May (Considine 2015). The transformation of the photograph into a poster was made possible due to the artist Bernard Rancillac's technical skills acquired in a trip in Cuba a year before, according to which the opaque projector could be applied to poster design allowing the creation of photo-based posters (Considine 2015). Rancillar designed the poster responding to the targeting of Cohn-Bendit as 'German' and a 'Jew' by both the sort-lived, right-wing weekly Minute and a member of the central committee of the French Communist Party, Georges Marchais. Marchais wrote in L'Humanite on the $3^{\text {rd }}$ of May: 'This Cohn-Bendit, because he is Jewish and German, takes himself to be the new Karl Marx. We 
would have willingly welcomed him if he hadn't come just to benefit from the education of our teachers, but we won't allow this agitator to continue playing 'Rudi le Rouge' here...In the present tumult, this Cohn-Bendit needs to be taken by the scruff of the neck and escorted to the frontier without due process.' (Banai 2013: 302-3). The poster was eventually reprinted by other members of the Atelier with the slogan 'Nous Sommes tous 'indesirables' (We are undesirables) in an effort to avoid any clashes with the leadership of the French Communist Party. [Figure 7] It was, nonetheless, the 'We are all German Jews' slogan that was chanted in the vibrant demonstrations in solidarity with Cohn-Bendit on the $24^{\text {th }}$ of May, in which both posters were carried around on placards.

The 'we' in the slogan refers to the students' effort to construct a collective subject by identifying with a group 'German Jews', which is not a classifiable sociological category. Ross demonstrates how the students' alliance with and inclusion of the 'Other' in several occasions since the police massacre of the Algerians on October 17, 1961 necessarily entailed a repudiation of dominant perceptions of French identity and a rejection of what the state has done in the name of the French (Ross 2002: 57). The 1961 massacre is crucial as the police not only annihilated the protesters, but they also attempted to erase any trace of the savage act and to keep the massacre out of view in media outlets. This was unprecedented for many young activists and signalled a turning point in the student movement, which from then on was not only concerned with student issues, but it embraced the cause of the repressed 'Other' of the recent French history. Rancière explains how the chanting of 'We are all German Jews' wouldn't have been rendered possible, if it weren't for those earlier moments of solidarity and inclusion of the 'Other' (Rancière 1998: 25-34). Nevertheless, for Ranciere, this was a negative gesture, in so 
far as it implied with whom the students did not identify with and the 'German Jews' was an empty signifier of the outsider, the annihilated and one who was made invisible (Rancière 1998). Either way Ross is correct in pointing out that 'in that peculiar construction of impossible 'we', a subjectivation that passes by way of the Other, lies an essential dislocation or fracturing of social identity that would define much of the political experimentation of May '68' (Ross 2002: 57).

This passing through the 'Other' often entailed the guerrilla fighter in Vietnam or the revolutionary in Cuba. The later version of the poster, which was divided into parts, bearing on the one half Cohn Benbit's and on the other half, Che's Guerrillero Heroico highlights the movement's internationalism and solidarity with other struggles [Figure 8]. Che's image was taken from Guerrillero Heroico, the famous poster created in 1967 out of the famous photograph of the revolutionary taken by Alberto Korda Díaz in a mass funeral service in Havana in 1960. The poster was gradually converted into an emblem of revolution and it was increasingly carried in demonstrations around the globe throughout 1968. It has been argued that it was Daniel CohnBendit who introduced the image to a street demonstration in May and it was through the French movement that poster was passed on to other activists in Europe, such as the Dutch group called The Provos, (Mir and Fitzpatrick 2006: 20). Photographs of the events depict posters of Che plastered on the walls of the Occupied Sorbonne and carried in the demonstrations. Similarly, photographs taken during the student protests in Mexico City and in Italy in the autumn of 1968 depict the wide use of the poster in placards and banners often accompanied by the " $i$ Hasta la Victoria Siempre!' ('Till the Victory Always’) and ‘UUnidos Venceremos!' ('United We will Win'). The movements did not only exchange ideas and practices, but also images. Che's image and his slogan 'One, two three Vietnams' reached far beyond the limits of one faction. His fight 
against exploitation, imperialism and capitalism, and for the liberation of the third world made his ideas so appealing to the Western youth. Despite the fact that he was a leader of a revolutionary vanguard and a senior figure in the Cuban government, his 'thoughts and deeds represent for these young people both an uncompromising, absolute, and radical rejection of the “system", and the revolutionary initiative of the vanguard to transform it.' (Löwy1973: 115). His image along Cohn-Bendit is a crucial moment of the movement's acknowledgement that their struggle was part of a global movement against exploitation, imperialism and capitalism.

\section{Conclusion:}

May '68's critique of hierarchy and institutional party political structures, its open assemblies, anti-hierarchical forms of organisation and experiments with direct democracy found its artistic expression in the function of the Atelier Populaire. The posters were products of a nonhierarchical collective effort of students, workers, professionals, activists and many others, who gathered together in discursive platforms, such as general assemblies and action committes in order to mobilise collective strategies of designing, producing and distributing them. The posters became then the weapons of the struggle, part of the movement's 'counter-information.' They challenged the bourgeois means of communication and distributed the movement's messages to the wider society. Revisiting the themes of the posters allows to rethink about the unique societal alliance made up of students, workers, farmers, migrant labourers and the unemployed, which expanded beyond Paris during May and afterwards. These groups shared a common struggle against capitalism, exploitation and repression, and demanded democracy, freedom, justice, and the rights for migrant workers and the unemployed. May ' 68 's unfulfilled potential, anticapitalist demands and revolutionary global aspirations as expressed in the slogans of the innovative Atelier Populaire posters can constitute a source of inspiration for contemporary anti- 
capitalist political struggles and their resisting of ecological crisis and the rise of nationalistpopulist and far-right political parties.

\section{Contributor details}

Dr. Antigoni Memou (PhD, Courtauld Institute of Art, MA University of Southampton) is Senior Lecturer in Visual Theories at the School of Arts and Digital Industries at the University of East London (U.K.). She has published in the journals Third Text, Philosophy of Photography, Epherema and Photographies. Her book Photography and Social Movements: From the Globalisation of the Movement (1968) to the Movement Against Globalisation (2001) was published by Manchester University Press in 2013.

Website: https://www.uel.ac.uk/Staff/m/antigoni-memou

\section{REFERENCES:}

Aron, R. (1969) The Elusive Revolution: Anatomy of a Student Revolt, New York: Praeger.

Artières, P. and Chassey, E. (2018) Images en Lutte : la Culture Visuelle de l' Extrême-

Gauche en France (1968-1974), Paris : Beaux-Arts de Paris Editions. [Exhibition Catalogue]

Ball, D. (2010) ‘The Tracts of May', French Politics and Society, 28, (1), Spring, pp. 77-91.

Banai, N. (2013) 'Sensorial Techniques of the Self: From the Jouissance of May $<$ APOS $>68$ to the Economy of the Delay', in Sherman D. J., van Dijk, R. Alinder, J. and Aneesh, A. The Long 1968: Revisions and New Perspectives, Bloomington and Indianapolis: University of Indiana Press.

Bulletin de Liaison Inter-Comités d' Action (B.L.I.C.), July 22, 1968 as cited in Ross, K. (2002) May '68 and Its Afterlives, Chicago and London: The University of Chicago Press. 
Considine, L. (2015) 'Screen Politics: Pop Art and the Atelier Populaire', Tate Papers, No. 24, Available at: https://www.tate.org.uk/research/publications/tate-papers/24/screen-politics-popart-and-the-atelier-populaire, (Accessed 20 September 2018).

Ferry, L. and Renaut, A. (1985) La Pensée '68, Paris: Gallimard.

Fink C., Gassert F. and Junker D., (eds.), (1998) 1968: the World Transformed, Cambridge: Cambridge University Press.

Fromanger, G. (1998) 'L' Art c' Est ce qui rend la vie plus Intéressante que l' Art' Libération, as cited in Ross, K. (2002) May '68 and Its Afterlives, Chicago and London: The University of Chicago Press.

Katsiaficas, G. (1987) The Imagination of the New Left: A Global Analysis of 1968, Masachussets: South End Press.

Lipovetsky, G. (1983) L'Ère du Vide: Essaie sur l'Individualisme Contemporaine, Paris: Gallimard.

Löwy, M. (1973) The Marxism of Che Guevara: Philosophy, Economics, and the Revolutionary Warfare, New York and London: Monthly Review Press.

Melucci, A. (1981) 'Ten Hypotheses for the Analysis of New Movements', in Pinto, D. (ed.). Contemporary Italian Sociology, Cambridge: Cambridge University Press, Cambridge.

Mir, A. and Fitzpatrick, J. (2006) 'Not Everything Is Always Black or White’, in Watson G., van Noord, G. and Everall, G. (eds.), Make Everything New: A Project on Communism, London and Dublin: Book Works and Project Arts Centre. 
Stracey F. (2014), Constructed Situations: A New History of the Situationist International,

London: Pluto.

Rohan, M. (1988) Paris '68: Graffiti, Posters, Newspapers and Poems of the Events of May

1968, London: Impact Books.

Ross, K. (2002) May '68 and Its Afterlives, Chicago and London: The University of Chicago

Press.

Touraine A., (1971) The May Movement: Revolt and Reform, Random House, New York.

Vermès, P. (2011) 'The Late Sixties', in Kugelberg, J. and Vermès, P. (eds.) Beauty Is in the

Street: A Visual Record of the May '68 Paris Uprising, London: Four Corners Books.

Wlassikoff, M., Riboud, M., Gautrand, J. C., Vermès, P. (2008) Mai 68 : L'Affiche en Heritage, Paris: Editions Alternatives.

\footnotetext{
${ }^{1}$ Les Annees 60: 1960-1969: La Decade Triomphante (The Sixties: 1960-1969: The Triumphant Decade) staged between 1 June- 30 September, 1986.

${ }^{2}$ Photographs of the graffiti by Jo Schnapp can be found in the publications: Lewino, W. (1968) L' Imagination Au Pouvoir, Eric Losfield Editeur, Paris 1968; Michel, A. (1998) Paroles de Mai : Affiches de l'Atelier Populaire des Beaux-Arts, Paris: Paroles, Paroles. Marc Rohan has also gathered a great number of graffiti in his publication: Rohan, M. (1988) Paris '68: Graffiti, Posters, Newspapers and Poems of the Events of May 1968, London: Impact Books.

${ }^{3}$ Their reports have been published in the following: Gilles Caron, Gilles Caron: Reporter 1967-1970, Paris: Éditions de Chêne, 1978; Claude Dityvon, Mai 68, Camera Obscura, Paris 1988; Hood Museum of Art, Dartmouth College, Protest in Paris 1968: Photographs by Serge Hambourg, Hanover N.H.: Hood Museum of Art, Dartmouth College; London: University Press of New England, 2006; Bruno Barbey, Mai 68 ồ l'Imagination au Pouvoir, Paris: Galerie Beaubourg, Éditions de la Différence, 1998.
} 